\title{
Az adójog értelmezése az Amerikai Egyesült Államok precedensjogában
}

\author{
Precedensrendszer - common law - adójog - jogértelmezés - \\ az adózás büntetőjogi megközelítése
}

A világ nagy jogrendszereinek vizsgálata, összehasonlító elemzése különleges és hasznos következtetések levonását teszi lehetővé. Az ilyen irányú kutatások lehetőséget teremtenek annak tanulmányozására, hogy egyes jogrendszerek miképpen szabályozzák az adókat, milyen jogi kérdésekre (kihívásokra) milyen megoldásokat alkalmaznak, illetve hogy hogyan hajtják végre a vonatkozó szabályokat. Az adott ország kultúrája is fontos tényező lehet: egyes nézőpontok szerint a nemzeti identitásból eredő jellemzők is komoly hatást gyakorolnak az adók megítélésére, más álláspontok szerint viszont a kulturális tényezőknek az olyan technikai területeken kevés jelentőségük van, mint az adópolitika, így az az egyik legnagyobb autonómiával rendelkező, másolható (más országoktól átvehető) terület. Ez a kérdés az új adók bevezetésénél, az azokhoz kapcsolódó teljesítési hajlandóság - vagy éppen ellenállás - körében is fontos lehet. ${ }^{1}$

Az angolszász, common law típusú jogrendszerek sajátos jellemzőkkel bírnak, másféleképpen közelítenek a jog világához, a jogalkotáshoz és a jogalkalmazáshoz, mint a római-germán jogcsalád országai. E tanulmány arra vállalkozik, hogy az adójogi jogértelmezés kérdését vizsgálja, elsősorban a 19., illetve a 20. század első két harmadában keletkezett - a mai jogalkalmazási elveket is meghatározó - bírósági ítéletek elemzésével, mégpedig elsősorban az egyik legjelentősebb, common law jogcsaládhoz tartozó országban, az Amerikai Egyesült Államokban. E feladat teljesítéséhez azonban elengedhetetlen, hogy röviden áttekintésre kerüljenek e jogcsalád általános jellemzői. Ezt követően az adójogi jogértelmezésre vonatkozó főbb precedenseket mutatom be, végül pedig egy konkrét példán - a költségek levonásának értelmezésén - keresztül világítom meg mélyebben a problémakört.

A vizsgálatok keretének kijelölésekor fontos szempont az is, hogy külön-külön elemezhető egy adott ország hazai adójogának és az adózásra (a kettős adóztatás elkerülésére) vonatkozó nemzetközi egyezményeinek értelmezése. ${ }^{2}$ Tekintettel a nemzetközi adójog sajátosságaira (annak speciális értelmezési kérdéseire), ez utóbbi terület jellemzőinek vizsgálata nem képezi a tanulmány tárgyát.

* Dr. Pfeffer Zsolt egyetemi adjunktus, Pécsi Tudományegyetem Állam- és Jogtudományi Kar, Pénzügyi Jogi Tanszék, e-mail: pfeffer.zsolt@law.pte.hu.

1 James, Kathryn: An Examination of Convergence and Resistance in Global Tax Reform Trends. Theoretical Inquiries in Law, 2010/2, 491.

2 Lásd például SмiтH, Robert Thornton: Tax Treaty Interpretation by the Judiciary. Tax Law, 1996/4, 845-892. 


\section{A precedensrendszer föbb jellemzői az angolszász országokban}

A jog-összehasonlítás területén végzett vizsgálódásai körében René David négy nagy jogcsaládot különített el: a római-germán, a common law, a szocialista és a vallási-tradicionális jogrendszereket. A common law országok - azaz az angolszász államok - jogrendszere másképp közelít a jogalkotáshoz és a jogalkalmazáshoz: míg a római-germán jogcsalád egyik fontos jellemzője, hogy előre megalkotják az absztrakt jogszabályt, addig a common law esetében az alapvető jogforrások - az írott, törvényi jog mellett - a felsőbb bíróságok által meghatározott, más bíróságokra kötelező érvényü ítéletek, pontosabban az ezekben kifejtett elvi tételek (azaz a bíró alkotta jog - a judge made law - az elsődleges). Az angol jog 1235-ben egyébként kifejezetten a hagyományos jelleg megőrzését juttatta kifejezésre (a római jog recepciója ellen foglalt állást): a Mertoni Statútum kezdődik a híres „Nolumus leges Angliae mutare” (azaz „Nem akarjuk Anglia törvényeit megváltoztatni”) mondattal, amely egyúttal kifejezi a jogi reformokhoz füződő alapvető angolszász attitüdöt is. ${ }^{3}$

Az ítéletekben megfogalmazott ratio decidendi, azaz a döntésben rejlö elvi megállapítások alkalmazhatóak más ügyekben is; mind a felek, mind pedig a bíróságok hivatkozzák a korábbi jelentősebb ítéletekben lefektetett elvi álláspontokat, jogszabály-értelmezéseket. (A precedens másik része az obiter dicta, amely az adott konkrét ügyben dönt; elvi, más ügyekben hivatkozható tartalma tehát nincs. $)^{4}$

A common law jogcsalád országainak törvénykezésében kiemelkedő jelentőségủek a hivatkozások, idézések. Ez azt jelenti, hogy mind a felek, mind pedig a bíróságok az érvelésük, indokolásaik során felhasználják korábbi bírósági ítéletek elvi tételeit. A 19. század végére az Egyesült Államokban a különböző gyüjteményekben kiadott ítéletek száma gyors növekedésnek indult (a kiadókat a profit iránti vágy vezérelte), azonban a válogatás hiánya megnehezítette a fontos és a lényegtelen, a „jó" és „rossz” ítéletek elkülönítését. Különböző módszereket dolgoztak ki arra, hogy egy ítélet „értékét” meghatározzák (például adatokat gyűjthetnek arról, hogy hányszor hivatkoztak rá). Megjegyzendő, hogy az ítéleteken kívül a jogtudósok hivatkozhatósága is felmerülhet (a római jogban ez létező, szabályozott megoldás volt, hiszen külön szabályt alkottak arra nézve, hogy mely jogtudósok munkásságát lehetett a jogalkalmazás körében felhasználni). ${ }^{5}$ Hasznosak emellett azok a kiadványok is, amelyek az ítéletekben rejlö elvi tételeket dolgozzák fel, elemezve a joggyakorlat fejlödését, alakulását is.

A common law jogrendszerek esetében a bírói jogalkotás (judge made law) az elsődleges jogforrás a kodifikáció termékeivel szemben (noha természetesen létezik kodifikáció, törvényi jog is e jogrendszerekben). Egyes jogbölcseleti álláspontok azonban elutasítják a bírók jogalkotásának lehetőségét. Ronald Dworkin például úgy érvelt, hogy választott politikusoknak kell kormányozniuk, és a bírákat senki nem

${ }^{3}$ Dean, Arthur: The Languishing Cause of Law Reform in Victoria. Res Judicatae, 1939-1941/1, 28.

${ }^{4}$ DaviD, René: A jelenkor nagy jogrendszerei. Összehasonlító jog. Közgazdasági és Jogi Könyvkiadó, Budapest, 1977, 306-310.

${ }^{5}$ ZöDI Zsolt: Citations of Previous Decisions and the Quality of Judicial Reasoning. Acta Juridica Hungarica, 2015/2-3, 130-131. 
választja, így nem felelősek a választók irányában. Ezenkívül, ha egy bíró új ,jogot” alkot, és azt visszamenőleges hatállyal alkalmazza az általa elbírálandó ügyben, akkor a vesztes fél nem azért lesz megbüntetve, mert megszegte a kötelességét, hanem azért, mert az esemény után egy új kötelességet alkottak. ${ }^{6}$

A precedensrendszer sajátosságai okán megemlíthető végül az a jellemző is, hogy az adózási kérdésekben nemcsak kifejezetten adójogi ítéletekben tett korábbi megállapításokat építik be a bíróságok a döntésekbe az adójogi törvénykezési tevékenységük során, hanem polgári jogi, gazdasági jogi vagy éppen klasszikus eljárásjogi kérdésekben - így például a bíróság kötelezettségei, a hatáskör terjedelme vagy a bizonyítékok felhasználhatósága tekintetében - álláspontot tartalmazó tételeket is felhasználnak. Ezen kérdések részletes vizsgálata azonban nem képezi a tanulmány tárgyát: a joggyakorlat az adójog értelmezése szempontjából kerül bemutatásra, amely kiválóan szemlélteti a (jog)történeti fejlődést, a judge made law által megvalósított jogfejlesztést is.

Vannak ugyanakkor olyan helyzetek, amikor egy-egy bírósági döntésben foglalt jogelvet a jogalkotó - annak sorozatos bírálata okán - törvényi úton felülír, és az alapul fekvő jogszabály módosítása folytán az adott ítéletben megfogalmazott jogelv már nem hivatkozható. Ilyen például a United States v. Davis eset (1962), ${ }^{7}$ amely a szövetségi jövedelemadó kérdésével foglalkozott (részvények átruházása válás esetén a volt feleségre, a volt feleség ügyvédjének fizetett adótanácsadói díj költségként nem ismerhető el). Miután számos bírálat érte az ítéletben foglalt jogelveket, a törvényhozás úgy döntött, hogy az akkori Internal Revenue Code (IRC) módosításával 1984-ben felülbírálja azokat. ${ }^{8}$ (Megjegyzendő, hogy 1982 és 1986 között a Kongresszus több mint húsz legfelsöbb bírósági döntést írt felül, számosat közülük a döntés meghozatalát követö két éven belül.) ${ }^{9}$

\section{A jogszabályok értelmezése}

A jogszabályok értelmezésének kérdésköréröl jelentős terjedelmü irodalom áll rendelkezésre. Vizsgálható e tevékenység az alanyok (jogalkotói, jogalkalmazói, jogirodalmi jogértelmezés), a módszerek (a négy alapvető módszer: nyelvtani, logikai, történeti, rendszertani, továbbá megemlítendő a teleologikus vagy céltételező értelmezés), valamint az eredmény szempontjából (helybenhagyó, megszorító, kiterjesztő értelmezés). ${ }^{10}$ Amikor az adóhatóság vagy a bíróság alkalmazza a jogot (jogokat és kötelezettségeket állapít meg, eldönt jogvitát), akkor fel kell tárni az absztrakt jogi norma tartalmát, azaz meg kell állapítani, hogy az adott történeti tényállást

\footnotetext{
${ }^{6}$ VISEgRÁdy Antal: Angolszász jog és politika. Dialóg Campus, Budapest-Pécs, 1999, 25.

7 United States v. Thomas Crawley Davis, 370 U.S. 65 (1962).

${ }^{8}$ BRINIG, Margaret F.: From Contract to Covenant. Beyond the Law and Economics of the Family. Harvard University Press, Cambridge-London, 2000, 313., 57. lábjegyzet, Id. még Slawski v. United States, 6 Ct. Cl. 433 (1984), valamint HJORTH, Roland L.: Divorce, Taxes, and the 1984 Tax Reform Act: An Inadequate Response to an Old Problem. Washington Law Review, 1986/1, 151-190.

${ }_{9}$ Mikva, J. Abner-Bleich, Jeff: When Congress Overrules the Court. California Law Review, 1991/3, 748.

10 Visegrády Antal: Jog- és állambölcselet. Dialóg Campus, Budapest-Pécs, 2003, 151-153.
} 
a jogalkotó miképpen akarta (akarhatta) megítélni, és ennek megfelelöen kell az álláspontot kialakítani (a döntést meghozni). Fontos egyrészt az, hogy a jogalkalmazó az értelmezés módszerét helyesen válassza meg, másrészt az, hogy a jogalkotó milyen szabályokat állapít meg ezzel kapcsolatban. A nyelvtani értelmezés alkalmazása nem mellőzhető, „hiszen a jogszabály nyelvi formában válik megismerhetővé. [...] az ún. céltételezéses értelmezés a nyelvi tartalom megismerése, majd pedig annak kudarca után válik elsődlegessé az értelmezés egyéb módszerei között”. A céltételezéssel elkerülhető, hogy a bírói ítélet abszurd eredményre vezessen. ${ }^{11}$ Az alapvető kérdés tehát, hogy mikor jelenthető ki az, hogy a nyelvtani értelmezés nem vezet eredményre az adott ügyben, és így helyette már a rugalmasabb, észszerübb döntést eredményező módszert kell alkalmazni, hiszen „Elemi formállogikai követelmény, hogy ha a nyelvtani értelem abszurd eredményre vezetne, azt el kell vetni, és más módszerek alapján más, a szó szerinti (exegetikus) értelemtől eltérő, adott esetben azzal szemben álló értelmet kell a jogszabályszövegnek tulajdonítani”. ${ }^{12}$

Ha az adójogi jogszabály túlságosan általános, a használt fogalmak meghatározása hiányos, akkor a jogalkalmazóra komoly felelősség hárul, hiszen ilyen esetben a mozgástere is jelentős. Az adóalany sincs könnyű helyzetben, hiszen elöre meg kell tudnia állapítani, hogy az adott jogi norma szövege alapján elfogadható lesz-e az adózás tekintetében hozott döntése, vagy sem (és ha tévedett a jogszerüség tekintetében, akkor viselnie kell annak jogkövetkezményeit). A jogértelmezés esetében kulcskérdés tehát, hogy a jogi norma tartalmát az adott ügy vonatkozásában megfelelő módon állapítsák meg.

Alapvetően két jogértelmezési koncepció vizsgálható: az egyik egy szigorúbb, az adózót preferáló megközelítés, ami azt jelenti, hogy a nyelvtani értelmezés szabályainak alapulvételével a jogi norma által használt kifejezésekböl (a szavak általános jelentéséből, írásjelekből) kell kiindulni, ha pedig azok kétségesek, akkor az adózónak kell kedvezni. A másik megközelítési módszer (értelmezés) szerint ugyanakkor már vizsgálni kell a mélyebb összefüggéseket, tartalmakat is, nem a szavak jelentéséből kell elsődlegesen kiindulni, hanem rendszertani összefüggéseket, adott esetben pedig a jogalkotói szándékot (célt) is kutatni kell. (Mindkét értelmezésröl a későbbiekben részletesebben szó lesz.)

Az első megközelítés bemutatására az 1873 -as United States v. Isham eset $^{13}$ hozható fel, amely egy, a bélyegadó-törvényhez kapcsolódó jogvitáról szólt, és amely rámutatott arra, hogy e szigorú értelmezés szerint nemcsak a szavaknak, hanem a szavak közötti írásjeleknek is komoly jelentőségük van. A jogvita alapjául szolgáló adótörvény felsorolta többek között, hogy adó tárgyát képezi a „memorandumcsekk” nevezetủ dokumentum, viszont nem úgy fogalmazott, hogy "memorandum, csekk" (a bíróság rámutatott a törvény szerkesztésének e hibájára is). Mivel az előbbi is létezik a kereskedelmi jogban (a bíróság vizsgálta ennek hátterét is), ezért az „egyszerü” csekkre nem volt alkalmazható az adójogszabály. Megfogalmaztak néhány alapvető értelmezési elvet is:

\footnotetext{
11 A Kúria Kfv.IV.35.631/2013/8. számú ítélete. Lásd még a 3188/2017. (VII. 21.) AB határozatot, ABH 2017, 1129.

12 15/2014. (V. 13.) AB határozat, $\mathrm{ABH}$ 2014. 337.

13 United States v. Isham, 84 U.S. 496 (1873).
} 
- A normaszöveget úgy kell értelmezni, ahogy azokat értik azon közegben, amelyben a törvény hatályosul, különleges tudás és készség nem szükséges az értelmezéshez, kivéve, ahol tudományos vagy müszaki kifejezéseket használnak.

- A pénzügyi eszköz adókötelezettségét az eszköz formája határozza meg, egyéb, külső tények nem vehetőek figyelembe.

- Ha vitás egy adott eszköz adóterhe, akkor kivételként kell értelmezni.

A bírósági álláspont azzal is magyarázható, hogy az Egyesült Államokban - a brit gyarmati idők rossz emléke nyomán - a bélyegadóra mint büntetésre tekintettek. ${ }^{14}$ A bélyegadó azt jelentette egyébként, hogy egy sor áru forgalomba hozatala adóköteles volt, így például újságok, kiadványok, jogi dokumentumok, engedélyek, biztosítások, kártyák, kockák. E termékeknek bélyeget kellett viselniük az adó megfizetésének igazolására, és a törvény megszegése súlyos börtönbüntetést vagy pénzbírságot vont maga után, de az is a szankciói közé tartozott, hogy ha az adott, adóköteles jogi dokumentum (például szerződés) után nem fizették meg az adót, akkor a jogi úton való érvényesíthetőség (felhasználhatóság) lehetősége sem volt biztosított. ${ }^{15}$ (A brit parlament például 1765-ben fogadott el egy ilyen törvényt, amely felháborodást váltott ki, és amely ellen a gyarmati kormányzatok tiltakoztak. $)^{16}$

Az Isham-ügyben is büntető feljelentés volt a kiindulópont (büntetöügy volt), ennek megfelelően a büntetőjogszabályok értelmezésére vonatkozó elvekből indultak ki, az angol törvénykezés elveit alapul véve. ${ }^{17} \mathrm{Az}$ angol Gurr v. Scudds ügyben (1855) ${ }^{18}$ is megállapítást nyert azon számos alkalommal hivatkozott tétel, amely szerint a kivételeket nagyvonalúan kell értelmezni, az adóalanynak kedvezve, és amelyek kiterjednek az olyan megállapodásokra is, amelyek tárgya jövőbeli áruk értékesítése, vagy amelyek rendes körülmények között, végső soron áruk értékesítésére vonatkoznak. ${ }^{19}$ Marshall föbíró 1820-ban megfogalmazta, hogy a büntetőjogszabályok szigorú értelmezése az egyéni jogok védelmén és azon a világos elven alapul, hogy a büntetés jogával a törvényhozó hatalom rendelkezik, nem az igazságszolgáltatás, így a törvényhozásnak, és nem pedig a bíróságnak áll jogában meghatározni, hogy mi minősül bűncselekménynek, és azt hogyan kell büntetni. ${ }^{20}$

A büntetőjogban alkalmazott értelmezési megközelítés azonban a joggyakorlatban csak az egyik lehetséges irányzat, számos más döntés foglalkozott azzal a kérdéssel, hogy az adók büntetésként értelmezhetőek-e vagy sem, és inkább úgy foglaltak állást, hogy nem büntetések, tehát az értelmezésnél más kiindulópontok is használandók.

\footnotetext{
${ }^{14}$ Cummings, Jasper L. Jr.: Supreme Court's Federal Tax Jurisprudence. American Bar Association, Section of Taxation, Washington, DC, 2010, 31-32.

15 Cummings: i. m. 32. Lásd az 1765. évi bélyegadó-törvény (Stamp Act) XVI. pontját.

${ }^{16}$ Cockfield, Arthur J.-MAYLES, Jonah: The Influence of Historical Tax Law Developments on Anglo-American Laws and Politics. Columbia Journal of Tax Lax, 2013/1, 58-62.

17 Cummings: i. m. 31-32.

${ }_{18}$ Gurr V. Scudds (1855), 11 Eseh. 190; 3 W. R. 457540.

19 The Laws of England, Volume VII, London, 1909, 540.

${ }^{20}$ United States v. Wiltberger, 18 U.S. 5 Wheat. 7676 (1820).
} 
Joseph Story bíró 1832-ben akként fogalmazott a Breed-ügyben, ${ }^{21}$ hogy „A jövedelemadóra és a vámokra vonatkozó törvények jogi szempontból nem büntető törvények, és ezért nem is értelmezhetőek szigorúan, ugyanakkor nem az alapvető jogokra, jogorvoslatra vagy a szabadság biztosítására szolgálnak, tehát a szélsőséges szabadelvü értelmezés sem alkalmazható. Ezeket a törvényeket az általuk használt szavak jelentése alapján kell értelmezni, és ha a jogalkotó szándéka megállapítható, akkor az, és csak az szolgálhat útmutatásként az értelmezéskor." Hozzátette, hogy nem állapíthatnak meg olyat a törvények eltorzításával, amely kívül esik a jogalkotó által használt szavak értelmén, illetve nem értelmezhetik szűkítő jelleggel a használt kifejezéseket akkor sem, ha a közérdek ezt úgy kívánná.

A későbbi jogfejlődésből is említhetőek olyan döntések, amelyek az adók, illetve a vonatkozó törvények értelmezésénél tagadták a korai büntetőjogi megközelítést, még akkor is, ha a jogalkotó okot adhatott az adók és a büntetések nem egyértelmű elhatárolására. Ebből a szempontból különösen érdekes az 1931-es United States v. La Franca ügy.22 E megközelítés, illetve probléma könnyen érthetővé válik, ha röviden bemutatásra kerül az ügy háttere, az eset ugyanis az 1919-1934 között fennálló szesztilalommal függött össze. Az érintett személy kis mennyiségben tiltott alkoholt árult az éttermében. A szesztilalmi törvény (National Prohibition Act) 35. §-a tartalmazott egy érdekes szabályt, amely szerint e törvény senkit nem mentesített a bódító alkoholok gyártásához vagy forgalmazásához kapcsolódó adó és más díjak megfizetése alól. Az adót az ilyen illegális tevékenységet végzőkkel szemben is meg kellett állapítani, és be kellett szedni, mégpedig kétszeres értékben (és ehhez kapcsolódott egy 500 USD értékű bírság csekély mennyiségü forgalmazás, és 1000 USD értékü bírság nagyobb mennyiségü gyártás esetén). A bíróság a következőket fogalmazta meg e rendelkezés értelmével kapcsolatban: „Ez valójában azt jelenti, hogy ha egy személy illegális eladást végez, akkor kétszeres összegü 'adót' kell fizetni azon korábbi szabályozás alapján, amely szerint még legális volt azon eladás, amelyet a hatályos jog nem tesz lehetővé. Az 'adó' (tax) egy kikényszeríthető, a kormányzat szolgáltatásaiért fizetendő hozzájárulás; egy 'büntetés' (penalty), ahogy a szó itt értendő, pedig egy kényszer, amelyet a törvény egy jogellenes cselekedet büntetéseként rendel alkalmazni. A két szó nem felcserélhető egymással. A lexikográfia müvészetének puszta gyakorlása nem változtathatja meg egy cselekedet vagy dolog lényegi jellegét, és ha egy kényszerítés nyilvánvalóan büntetés, akkor az nem azonositható az adóval egyszerüen azáltal, hogy annak nevezik." A bíróság szerint fontos az a kérdés, hogy valakit lehet-e polgári jogi keresettel büntetőjogi felelősségre vonni (azaz lehet-e polgári úton adónak nevezett, valójában azonban büntető pénzbírságot érvényesíteni), hiszen ez már alkotmányossági aggályokat is felvet, így e két szankciótípust lehetővé tevő eljárásokat el kell határolni az alapjaikat képező fogalmak tényleges tartalma alapján.

(Az adó meghatározásával kapcsolatban megjegyzendő egyébként, hogy a Welch v. Henry ügyben ${ }^{23}$ is megállapították, hogy „az adó nem az adózóra kiszabott bün-

\footnotetext{
21 United States v. Breed et al., 24 F. Cas. 1222 (1832).

22 United States v. La Franca, 282 U.S. 568 (1931).

${ }^{23}$ Welch v. Henry, 305 U.S. 134 (1938).
} 
tetés, viszont nem is olyan kötelezettség, amelyet szerződésben vállal. Ellenben a kormányzati költségek olyanok közötti felosztásának eszköze, akik bizonyos mértékig élvezik a kormányzat által nyújtott előnyöket, ugyanakkor viselniük kell ennek a terheit.")

Az adók és a büntetések kérdése az 1996-os United States v. Reorganized CF\&I Fabricators ügyben ${ }^{24}$ is felmerült. A kiinduló tényállási elem szerint a CF\&I Steel Corporation és a leányvállalatai arra voltak kötelezve, hogy évente befizessenek egy bizonyos összeget a nyugdíjalapba. A CF\&I 1989-ben nem teljesítette a befizetési kötelezettségét, és a csődbíróságtól csődvédelmet kért. A kormány azonban adóhiányt és $100 \%$-os mértékű bírságot állapított meg, figyelemmel a csődtörvény vonatkozó rendelkezéseire. A bíróság megvizsgálta a tényleges jelentést, és arra a következtetésre jutott, hogy ez büntetés volt, és nem pedig adó a csőd szempontjából. ${ }^{25}$

Megemlítethető, hogy a jogértelmezés kérdései tekintetében tett más, általános megállapítások is relevánsak lehetnek adójogi jogvitákban. Ebben a körben kiemelhető a Crooks v. Harrelson eset (1930), ${ }^{26}$ amelyben általános, nem adójogi jogvitákkal foglalkozó ügyekre is hivatkozott a bíróság. ${ }^{27}$ A megfelelő, a jogalkotó tényleges szándékával összhangban álló értelmezés kérdése akkor válik szembetűnővé, amikor különböző szavak valódi értelmét keresik (akár azt, hogy mit jelenthet a jövedelem, a hagyaték vagy egy olyan kötőszó, mint az és egy jogszabályi rendelkezésben, de az is felmerülhet kérdésként, hogy az adott szavakat a szó hétköznapi értelmében kell használni, vagy technikai szempontból kell-e értelmezni). ${ }^{28}$ Általában „a szavak közismert és elfogadott jelentése szolgáltatja a jog értelmezésének alapját”. ${ }^{29}$

Az előző bekezdésben említett döntés rámutatott a később tárgyalandó második értelmezési (megközelítési) lehetőségre is: jelentős ügyekben hozott ítéletek támasztják alá, hogy a jogszabály betűjétől való eltérés igen is igazolható, ha a szó szerinti alkalmazás olyan fokú abszurditáshoz vezetne, amely már sértené a jó erkölcsöt vagy a józan észt, ${ }^{30}$ így a bíróságoknak némely esetben rugalmasabbnak kell lenniük. Ugyanakkor nem elegendőek pusztán a szigorú, kifogásolható vagy abszurd jogkövetkezmények ezen elv alkalmazásához, csak különösen indokolt esetben állhat fenn a kivételes elbírálás. A jogszabályokat jó szándékkal alkotják, és amikor a gyakorlatban érvényesülnek, akkor derülhet ki még a jogalkotó számára is, hogy az eredmény abszurd vagy más módon kifogásolható. Különösen indokolt esetben tehát a törvény betű szerinti értelmezését el kell vetni, és a jogszabály szellemét, célját, a Kongresszus szándékát kell alapul venni. A bíróság azonban hangsúlyozni kívánta e módszer kivételes jellegét.

\footnotetext{
24 United States v. Reorganized CF\&I Fabricators of Utah, 518 U.S. 213 (1996).

${ }^{25}$ Cummings: i. m. 36., lábjegyzet.

${ }^{26}$ Crooks v. Harrelson, 282 U. S. 55 (1930).

${ }^{27}$ Lásd még például a Chevron-doktrínát. Cummings, Jasper L. Jr.: The Supreme Court's Deference to Tax Administrative Interpretation. Tax Lawyer, 2016/2, 423-427.; illetve Chevron, U.S.A., Inc. v. Natural Res. Def. Council, Inc., 467 U.S. 837, 842-43 (1984).

${ }^{28}$ Lásd például Billings v. United States, 232 U. S. 261 (1914).

${ }^{29}$ Maillard v. Lawrence, 57 U.S. 251 (1853).

${ }^{30}$ A döntés utal arra, hogy ez a megállapítás összevetendő a Pirie v. Chicago Title and Trust Company, 182 U. S. 438. esettel (451-452.).
} 
Ezen általános megközelítésre építve elemezte a bíróság az adójogi jogviták speciális helyzetét, kifejezetten rögzítve, hogy nem szabad figyelmen kívül hagyni azt a tényt, hogy adójogszabály érintett az ügyben, és ilyen esetben a normaszöveg betűjéhez különös szigorúsággal kell ragaszkodni (például, hogy a hagyatéki juttatások az adójogszabály szerinti jövedelemnek minősülnek-e, vagy sem; e kérdés megválaszolásához e jogintézmények jellegét kellett elemezni). Hivatkozott e döntés a United States $v$. Merriam esetre ${ }^{31}$ amelyben megállapították, hogy a kormány részéről az adóztatás egy gyakorlati kérdés, és a hangsúly az adótárgyakon van a jogi kifejezésekkel szemben. Ugyanakkor az adójogszabályok esetében a szavak betű szerinti jelentésének alkalmazása a legfontosabb; kiterjesztő értelmezés nem engedhető meg, más elemek nem vonhatóak a hatályuk alá. „Ha a szavak jelentése kétséges, a kétség a Kormány hátrányára oldandó fel, és az adózónak kell kedvezni." („If the words are doubtful, the doubt must be resolved against the Government and in favor of the taxpayer" - idézte a döntés a Gould v. Gould esetet.) ${ }^{32}$ A McFeely v. Commissioner ügyben ${ }^{33}$ is ugyanezt az álláspontot használták fel. („Here the rule obtains that a taxing statute, if of doubtful intent, should be construed favorably to the taxpayer.")

Az említett United States $v$. Merriam ítélet a szabály angol eredetét is megemlítette, visszanyúlva az angol törvénykezéshez. Lord Cairns a Partington v. AttorneyGeneral ügyben (1869) ${ }^{34}$ megfogalmazta az adóügyi törvények lényegét (elvét): ha az adóalanyt a törvény betüje szerint meg kell adóztatni, akkor meg kell adóztatni, bármennyire is nagy tehernek tűnik annak teljesítése a bíróság számára. A Korona az adóbevétel megszerzése érdekében önkényesen nem sorolhat a törvény hatálya alá egyébként oda nem tartozó adótárgyat, az adótárgy mentes az adó alól, bármennyire is másképpen megítélhetőnek tünik a jogszabályok szelleme szerint az ügy. Ha pedig bármilyen törvény tartalmaz méltányossági rendelkezést, az adójogszabály esetében az nem alkalmazható, ahol a törvény szövegéhez lehet ragaszkodni. Az 1902-es Eidman v. Martinez ügyben ${ }^{35}$ az amerikai bíróság is említi az angol bíróságok azon alapvető elvárását (a vonatkozó ítéletek felsorolásával), hogy ha az adóztató hatalom valamilyen tárgyat adóztatni kíván (vagy rá más közterhet akar kivetni), akkor az arra vonatkozó törvényt egyértelmű nyelvezettel kell megfogalmaznia (alapvető követelmény tehát, hogy az akaratát egyértelmüen fejezze ki). E döntés egyébként hivatkozott a Hartranft $v$. Wiegmann eset döntésére ${ }^{36}$ amelynek tényállása szerint az adózó savval tisztított kagylókat vásárolt Londonban, és azokat importálta. A vámjogszabály - többek között - a „gyártott” (manufactured) termékekre vonatkozott. A bíróság úgy találta, hogy a mentesség esete áll fenn, hiszen attól még, hogy kézi vagy gépi munkavégzésnek vetik alá az adott dolgot, még nem jelenti szükségszerüen azt, hogy "gyártott” jellegü is lesz, hiszen továbbra is csak kagylókról van szó, a használat módja (a rendeltetés) nem változott. Ebben

\footnotetext{
31 United States v. Merriam, 263 U. S. 179 (1923).

32 Gould v. Gould, 245 U. S. 151, 153. (1917).

${ }^{33}$ McFeely v. Commissioner 296 U.S. 102 (1935).

34 Partington v. Attorney General, LR 4 HL 100, 122 (1869).

${ }^{35}$ Eidman v. Martinez, 184 U. S. 578, 583. (1902).

${ }^{36}$ Hartranft v. Wiegmann, 121 U.S. 609 (1887).
} 
a jogvitában tehát a manufactured szó értelmezése volt a kulcskérdés, és annak tartalmát kellett megfelelően meghatározni (kiterjesztő lett volna az értelmezés, ha olyan terméket vonnak a vámjogszabály hatálya alá, amely nem felel meg az adott kifejezés tartalmának, mert az nem volt „gyártott”).

Az említett álláspontokból az következik, hogy az adójogszabályok értelmezésekor sem a kiterjesztő, sem pedig a megszorító jogértelmezés nem alkalmazható, a szavak jelentéséből kell kiindulni; kiterjesztő értelmezéssel nem lehet olyan tárgyakat (tevékenységeket, jövedelmeket) az adójogszabály hatálya alá vonni adótárgyként (vagy szűkítő értelmezéssel megtagadni az adó alapját csökkentő tételként történő elismerést), ${ }^{37}$ amelyek a szavak jelentése alapján nem tartoznak a törvény hatálya alá (vagy amelyek beletartoznak az érvényesíthető tételek körébe). Csak kivételes esetben van lehetőség a normaszövegtől való elrugaszkodásra, a jogszabály célja (,a jogszabály szelleme”) kivételesen írhatja felül a törvény betüit. Ha a szavak vizsgálata nem vezet eredményre, akkor az adójogszabály tartalma nem egyértelmú, viszont a kétséges normatartalom nem értékelhető az adóalany terhére, az adóalany érdekeit kell figyelembe venni, azokat kell előnyben részesíteni. A jogalkotó felelőssége tehát, hogy ha valamely adótárgyat adóztatni akar, vagy ha valamely költség érvényesíthetőségét (az adóalapból történő levonhatóságát) meg akarja tagadni, akkor azt tegye egyértelművé.

A vizsgált korszak joggyakorlatában ennek megfelelően rendszerint a szavak általános jelentéséből indultak ki; sem a kiterjesztő, sem pedig a megszorító értelmezést nem alkalmazták. Példaként említhető, amikor a tulajdon (property) fogalmát értelmezte a bíróság a Lynch v. Alworth-Stephens Co. ügyben (1925) ${ }^{38} \mathrm{~A}$ jogkérdés az volt, hogy ha egy bánya múvelésének jogát bérbe adják, és a kitermelt érc után dijat fizet a bérlő, akkor alkalmazható-e adóalap-csökkentő, indokolható tételként a bánya mint tulajdon (property) „kimerülése” (exhaustion). A bíróság szerint semmi sem indokolta, hogy a tulajdon szót megszorító jelleggel értelmezzék, és emiatt az indokolható csökkentést kizárják, arra is tekintettel, hogy a bánya egy speciális (ténylegesen kimeríthető) vagyontárgy. Az eljáró bíróság vizsgálta a korábbi releváns döntéseket és az alapul fekvő jogszabályokat, és megállapította, hogy a korábbi döntések során alkalmazott jogi háttér más megítélés alá vonandó, hiszen nem az exhaustion...of property kitételt, hanem a depreciation (értékcsökkenés) kifejezést használta a bevétel körében levonható jogcímek között a tételes jog. ${ }^{39} \mathrm{~A}$ bíróság egyetértett a körzeti fellebbviteli bíróság azon megállapításával, amely szerint a törvény világos, nyilvánvaló, észszerü értelmezése részesítendő elönyben, nem pedig a furcsa, megszorító, rejtett értelem keresendő, amelyet csak találékonysággal, éles elmével lehet megismerni. Így egyértelmű szövetségi normatartalom, egyszerủ megítélésü ügy esetén szükségtelen a helyi jogra támaszkodni vagy olyan érveket vizsgálni, amelyek a Kongresszus adóelkerülésre vonatkozó szándékaira épülnek. ${ }^{40}$

\footnotetext{
${ }^{37}$ Lásd példaként a Neuberger v. Commissioner of Internal Revenue 311 U.S. 83 (1940) ügyet.

${ }^{38}$ Lynch, Execurtix, etc. v. Alworth-Stephens Company 267 U.S. 364 (1925).

${ }^{39}$ Ld. a United States v. Biwabik Mining Co. 247 U.S. 116 (1918) és a Von Baumbach v. Sargent Land Co. 242 U.S. 503 (1917) ügyeket.

${ }^{40}$ Ld. a Corliss v. Bowers, Collector of Internal Revenue 281 U.S. 376 (1930) ügyet.
} 
Fontos kiemelni azonban a jogértelmezés egy sajátos aspektusát, nevezetesen azt, hogy a jogértelmezés és az adóelkerülés milyen módon függhet össze. A jogértelmezéshez kapcsolódó viták rendkívül jelentősek az adóelkerülés szempontjából: az értelmezés során ugyanis két álláspont közül kell választani. Az első a betü szerinti (szigorú) értelmezés, a másik pedig a szándékot (a célt) kutató értelmezés. Az Egyesült Államokban külön vizsgálatokat is végeztek annak érdekében, hogy kiderítsék azt, hogy van-e kapcsolat a bíró végzettsége, tapasztalata, etnikai hovatartozása és aközött, hogy melyik módszert részesíti előnyben az ilyen típusú kérdést felvető jogviták elbírálásakor. ${ }^{41}$

Az előzőekből következően érdemes néhány olyan esetet is említeni, ahol a bíróság nem szigorúan a jogi norma szövegéből indult ki, hanem megpróbálta annak mélyebb értelmét is feltárni. Már az 1910-es, illetve 1920-as években megjelentek azok a bírói és tudósi megközelítések, amelyek a betű szerinti, szigorú értelmezésre épülő megközelítést támadták (pl. Louis Brandeis, Roscoe Pound, Ernst Freund, Benjamin Cardozo). Az Irwin v. Gavit ügyben (1926) ${ }^{42}$ a bíró azt vizsgálta, hogy a jövedelemadóról szóló törvény szerinti jövedelemnek minősülnek-e azok a rendszeres kifizetések, amelyeket az adófizető kap egy, a gyermekének szánt vagyonból. Holmes bíró visszautasította az alaki megközelítést, és úgy fogalmazott, hogy „azt szokták mondani, hogy az adójogot az adózók számára kedvező módon kell értelmezni. Ugyanakkor nem indokolható sem a kétséges, sem pedig a túlzó értelmezés." Másik példaként az Untermeyr v. Anderson eset (1928) ${ }^{43}$ említhető, amelyben a jogkérdés az volt, hogy az ajándékozásra vonatkozó törvénynek lehet-e visszaható hatálya, azaz adóztatható-e a törvény kihirdetése előtt, a törvényalkotás idején juttatott ajándék. Míg a McReynolds bíró által megfogalmazott többségi vélemény szerint az adózó javára kellett dönteni, idézve azt, hogy biztosítani kell az adójog bizonyosságát, addig különvéleményében Louis Brandeis bíró rámutatott arra, hogy az ajándékozásra vonatkozó adó célja az adóelkerülés kiküszöbölése volt, így igenis fennállhat visszaható hatály, hiszen a tárgy keretei túlléphetőek annak érdekében, hogy maga a tárgy védett legyen. A Milliken v. United States ügyben (1931) ${ }^{44}$ Brandeis bíró álláspontját egyébként elfogadták („a tax is not necessarily unconstitutional because retroactive”). Az 1930-as évekre a bíróságokat a kormányzat javára való ítélkezésre ösztönözték az olyan esetek, amikor a szigorú értelmezés az adóelkerülést támogatta volna. Benjamin Cardozo bíró a Woolford Reality v. Rose (1932) esetben ${ }^{45}$ egyenesen úgy fogalmazott, hogy az „elme lázadt” azon értelmezés ellen, amely az adózónak kedvezett volna, mert a Kongresszusnak az adózó által megjelölt veszteség levonhatóságának biztosítása biztos nem állhatott a szándékában. Egy évvel később, a Burnet v. Guggenheim ügyben ${ }^{46}$ pedig már alapvetően félretették az adózóknak kedvező értelmezési megközelítést, megfogalmazva, hogy „ennek a szabály-

\footnotetext{
${ }^{41}$ LIKHOVSKI, Assaf: The Duke and the Lady: Helvering v. Gregory and the History of Tax Avoidance Adjudication. Cardozo Law Review, 2004/3, 969, 973.

42 Irwin v. Gavit, 268 U.S. 161 (1926).

43 Untermeyr v. Anderson 276 U.S. 440 (1928).

44 Milliken v. United States 283 U.S. 15 (1931).

45 Woolford Reality v. Rose, 286 U.S. 319 (1932).

${ }^{46}$ Burnet v. Guggenheim 288 U.S. 280 (1933).
} 
nak sok oldala van. Mindegyiket meg kell vizsgálni, ha valaki bölcsen akarja alkalmazni. Az értelmezés, amely nagyvonalú egy adózónak, kevésbé lehet az egy másiknak. Valakinek egyensúlyt kell találni az elönyök terén."47

A fent kifejtettek sajátos értelmezést nyerhetnek az ún. public policy doctrine ${ }^{48}$ szempontjából, hiszen mégis megengedhető olyan döntés, amely figyelembe vesz bizonyos külső szempontokat is. E tekintetben, a közérdek érvényesítésének szempontjából rendkívül lényeges az Egyesült Államok jogalkalmazásának történetéből a Bob Jones University v. United States eset ${ }^{49}$ is, amelyben egy adókedvezmény (adómentesség) érvényesítésének megtagadása merült fel. Az akkori Internal Revenue Code (IRC) ${ }^{50}$ adómentességet biztosított olyan szervezeteknek, amelyeket kizárólag vallási, jótékonysági vagy oktatási céllal hoztak létre és müködtettek. Az Internal Revenue Service (IRS, az amerikai adóhatóság) 1970-ben úgy foglalt állást, hogy nem illethet meg adómentesség olyan magániskolát, amely nem tesz eleget az antidiszkriminációs (antirasszista) politika követelményeinek, hiszen az ilyen iskola nem minősülhet „jótékonysági” intézménynek. A pert indító Bob Jones University olyan gyakorlatot folytatott, hogy felvett egyedülálló feketéket, de megtagadta a felvételt olyanoktól, akik vegyes házasságban éltek, vagy akikről tudták, hogy támogatják a vegyes házasságokat, kapcsolatokat. ${ }^{51} \mathrm{E}$ felvételi szabályok miatt a szövetségi adóhivatal, az IRS megtagadta az adómentesség érvényesítését. A kerületi bíróság megállapítása szerint az IRS túllépte a hatáskörét, amikor megvonta az iskolától az adómentességet jelentő státuszt, és megsértette a felperesnek az Alkotmány első kiegészítésében foglalt vallási jogait (mivel nagy hangsúlyt fektettek az oktatás keretében a keresztény vallásra és etikára). A fellebbviteli bíróság azonban ellentétes álláspontot fogalmazott meg; a Legfelsőbb Bíróság megállapította végül, hogy az Alkotmány hivatkozott kiegészítése nem tiltja az IRS számára, hogy visszavonja egy vallási alapon müködő egyetem adómentességét annak érdekében, hogy érvényre juttasson egy olyan kötelező célkitűzést, mint a rasszizmus visszaszorítása.

Annak kérdésében, hogy ez a megoldás mennyire elfogadható, kiindulópontként az határozható meg, hogy az adók elsődleges célja a közkiadások teljesítéséhez szükséges pénzügyi fedezet megteremtése, míg másodlagos céljuk gazdaság- és társadalompolitikai célkitüzések megvalósítása is lehet. E célok megvalósításának

\footnotetext{
47 LIKHOVSKI: i. m. 980-981.

${ }^{48}$ A public policy doctrine kérdéséről (előzményekről) lásd STEPHAN, Paul B. III.: Bob Jones University v. United States: Public Policy in Search of Tax Policy. Supreme Court Review, 1983, 38.

49 Bob Jones University v. United States, 461 U.S. 574 (1982).

${ }^{50}$ A szövetségi adójog átfogó törvénykönyve. https://www.law.cornell.edu/uscode/text/26. (2019. 09. 18.).

${ }^{51} \mathrm{Az}$ általános társadalmi, jogi háttér (attitűd) megvilágítására említhető a Loving et ux. v. Virginia, 388 U.S. 1 (1967) ügy, amelyben külön érvénytelenítenie kellett a Legfelsőbb Bíróságnak egy Virginia állam bírósága által meghozott büntető ítéletet, amely azon alapult, hogy egy fekete nő és egy fehér férfi házasságot kötött 1958-ban Washington D.C-ben, mivel az államuk (Virginia) joga tiltotta és büntette a vegyes házasságokat (interracial marriages). Miután a pár visszatért Virginiába, büntetőeljárás indult ellenük, egy év felfüggesztett szabadságvesztésre ítélték őket azzal a feltétellel, hogy elhagyják az állam területét, és nem térnek vissza 25 évig együtt. Az ítélet indokolásában megfogalmazták, hogy az Isten megteremtette a különböző fajokat, amelyeket különböző földrészekre helyezett, és az a tény, hogy különböző fajokat teremtett, bizonyítja, hogy nem akarta, hogy azok keveredjenek. A pár elhagyta az állam területét, viszont később a Legfelsőbb Bíróság - a XIV. kiegészítésre hivatkozva - érvénytelenítette ezt az ítéletet.
} 
eszközeként használhatja az adórendszert, illetve más közterheket is a jogalkotó. Ilyen esetekben is fontos, hogy az adójogi norma tartalma világos legyen; a jogalkotó nem delegálhatja a jogalkalmazóra annak eldöntését, hogy általában milyen döntés áll összhangban az általános politikai célkitűzésekkel. Garanciális jelentőségü tehát az, hogy a jogértelmezésen keresztül milyen mozgásteret biztosít a törvényhozás - vagy éppen a bíróság - az adóhatóság számára, jogosult-e ez utóbbi tágan értelmezni az adójogszabályokat, indokolható-e mindez általános, elfogadható célkitűzések megvalósítása érdekében. Különösen érdekes mindezek tükrében azon joggyakorlati tétel, amely szerint „Egy köztisztviselö vagy egy szerv azon joga, hogy alkalmazza a szövetségi jogot és hogy elöírásokat fogalmazzon meg, nem jelenti azt, hogy jogalkotási hatáskörrel is rendelkezne". 52

A jogértelmezés kérdését vizsgálni szükséges a rendeltetésszerü joggyakorlással összefüggésben, az adózói oldalról is. A rendeltetésszerü joggyakorlás követelményével összhangban áll az, ha az adózók a jogszabályokat úgy értelmezik, hogy abból előnyük származik, de ez az értelmezés a jogszabály rendeltetésével nem lehet ellentétes. Ez a kérdés más adórendszerekben is megjelenik, így célszerü egy rövid kitekintés e körben is. A magyar Kúria egyik ítéletében a következőképpen fogalmazott: „Utal a felülvizsgálati bíróság arra a töretlen bírói gyakorlatra, mely szerint önmagában nem jogellenes, ha az adózók a jogszabályokat úgy értelmezik, melyböl adóelönyük származik, ugyanakkor ez az értelmezés nem lehet ellentétes a jogszabály rendeltetésével." "53 Viszont senki nem kötelezhetö arra, hogy több adót fizessen annál, mint amennyi a törvényböl következik, ugyanakkor, amit a törvény elöír, azt meg kell fizetni a közteherviselés követelményéből adódóan (ha ugyanis a mindenkit terhelő felelősség alól az adózók kibújhatnának, akkor az adóterheket a jogkövetőkre csoportosítanák át). ${ }^{54} \mathrm{Az}$ adójogszabályok értelmezésének ezen, szigorúbb megközelítését más országok jogrendszereiben is elfogadják (például Franciaországban, Belgiumban), a törvényesség és a nullum tributum sine lege ${ }^{55}$ elvből kiindulva. A ténylegesen visszaélésszerü magatartások szankcionálására pedig a joggal való visszaélés tilalmának elve kínálhat megoldást. Németországban viszont az I. világháborút követően az adójogszabályok gazdasági értelmezésének elvét mondta ki a jogalkotó; erről a megközelítésröl később lemondtak, azonban az alkotmánybíróság gyakorlata nem volt mindig egyértelmü ebben a kérdésben (azaz, hogy az adójogszabályokat szüken vagy tágan kell-e, illetve lehet-e értelmezni). Az újabb adójogszabályok már nem mondták ki a gazdasági értelmezés koncepcióját. ${ }^{56}$

Az Egyesült Királyság esetjogában is alapvető elv, hogy mindenkinek joga van úgy rendezni az adóügyeit a vonatkozó törvények szerint, hogy a lehető legkisebb

${ }^{52}$ A Dixon v. United States, 381 U.S. 68, 77 n. 9 (1965) idézte a Manhattan General Equipment Co. v. Commissioner, 297 U.S. 129 (1936) ügy megállapítását.

53 A Kúria Kfv.l.35.173/2011/5. számú ítélete.

54 17/2019. (V. 30.) AB határozat, 83. pont.

55 Lásd e kérdésről részletesebben PfefFER Zsolt: A nullum tributum sine lege elv. Jogtudományi Közlöny, 2015/1, 531-540.

56 VANistendael, Frans: Legal Framework for Taxation. In: ThuRonyl, Victor (ed.): Tax Law Desing and Drafting. Washington, International Monetary Fund, 1996, 35-38. 
mértékű adót fizesse. Ha ez megvalósítható, akkor sem az adóhivatal, sem pedig a többi adózó nem kényszerítheti őt arra, hogy több adót fizessen (IRC v. Duke of Westminster, 1936). Egy másik ügyben pedig már a következőket fogalmazták meg: az előre megtervezett ügyletek sorozatának pénzügyi következményeit egészében kell megítélni, nem pedig elkülönülten (W.T. Ramsay Ltd. v. Inland Revenue Commissioners, 1981). ${ }^{57}$

Megjegyzendő, hogy a joggal való visszaélés tilalmával szemben az abszolút jogok megközelítése állítható. E koncepció azt jelenti, hogy a jog védelmezi azokat a magatartásokat is, amelyek megfelelnek ugyan valamely jogszabályi rendelkezésnek, viszont a céljuk alapján kifogásolhatóak. Az angol jogban ezt meglehetősen határozottan a Lord Macnaghten a Mayor of Bradford v. Pickles ügyben (1895) fogalmazta meg a bíróság. Az alapul fekvő ügy tényállásában Mr. Pickles szándékosan elvezette a vizet, s ezzel megfosztotta attól a települési polgártársait. Megállapították, hogy mindez talán megdöbbentett volna egy morálfilozófust, viszont nincs olyan törvény Angliában, amelyik megakadályozhatná az embereket abban, hogy olyan „modortalanok, önzőek és kapzsik legyenek, amilyenek emberek egyáltalán lehetnek”. Ez a dura lex sed lex („kemény jogszabály, de jogszabály”) elv érvényesülését jelenti. ${ }^{58}$ A magyar polgári jog (és nem mellesleg az adójog) természetesen elismeri a joggal való visszaélés tilalmát; az angolszász jogtól ez azonban alapvetően idegen, ${ }^{59}$ eltérő alapállásból közelít e kérdéshez.

Végül fontos kérdésként említhető, hogy az Egyesült Államok különböző államaiban egységesen szükséges alkalmazni (és ennek megfelelően értelmezni) a szövetségi jogot, figyelemmel az egyenlő bánásmód követelményére. A Thomas v. Perkins ügyben (1937) ${ }^{60}$ megállapítást nyert, hogy „A szövetségi jövedelemadóról szóló törvény országosan egységesen alkalmazandó jogszabály, kivéve, ha a Kongresszus rendelkezik úgy, hogy az adott állam jogától is függ az alkalmazása”. ${ }^{1}$

\section{A jogalkalmazás egyik sarkalatos kérdése: a költségek figyelembevétele}

Bármely adó esetében kulcskérdés az adó alapjának megállapítása. A jövedelmet, nyereséget terhelő adók esetében a jogalkotó általában lehetővé teszi, hogy a megszerzett teljes bevételből az adózó levonja a bevétel megszerzéséhez szükséges, a vállalkozási tevékenységgel összefüggő költségeket. Ilyen esetben alapvető kérdés, hogy a jogi szabályozás mit fogad el érvényesíthető költségként, és mit zár ki ebből a körből. Az amerikai adójogban a költségek figyelembe vételére a deduction (levonás) kifejezés használatos („There shall be allowed as a deduction all the ordinary and necessary expenses paid or incurred during the taxable year in

\footnotetext{
57 VANiSTENDAEL: i. m., 39-41.

58 Gutteridge, H. C.: Abuse of Righst. Cambridge Law Journal, 1933/1, 22.

59 CRABB, John H.: The French Concept of Abuse of Rights. Inter-American Law Review, 1964, 1.

60 Thomas, Collector, v. Perkins et al., 301 U.S. 655 (1937).

61 Thomas, Collector, v. Perkins et al., 301 U.S. 655 (1937). Ld. még pl. City of New York v. Feiring, 313 U.S. 283 (1941).
} 
carrying on any trade or business, including...”). Az IRC-ben külön rész ${ }^{62}$ foglalkozik azzal, hogy az egyének és a vállalkozások milyen tételeket vehetnek figyelembe. A 162. § a) pontja általános szabályként rögzíti ennek megfelelöen, hogy minden, az adóévben a vállalkozással (foglalkozással) kapcsolatban kifizetett vagy felmerült szokásos és szükséges kiadás (ordinary and necessary business expenses) vonható le. A jogszabály egy példálózó felsorolást is tartalmaz, így ebbe a körbe tartoznak különösen a személyi jellegű kifizetések (munkabérek), az utazási költségek; de azt is nevesíti, hogy mi az, ami kifejezetten kizárt ebből a körből (például tisztviselöknek kifizetett jutalékok, kenőpénzek). Az IRC e részben külön fejezetekben szabályozza a speciális költségelemeket (például a 164. §-ban sorolja fel azt, hogy mely adók hogyan írhatóak le költségként). Mivel a gazdasági élet különböző, kifejezetten nem szabályozott költségeket képes produkálni, ezért az adójogi gyakorlatban is különösen hangsúlyos kérdés, hogy a törvény által nem említett kiadások az általános szabályok alapján levonhatóak-e költségként, vagy sem. Ennek megfelelően kulcskérdés a „szokásos és szükséges üzleti kiadások” (ordinary and necessary business expenses) fogalmának értelmezése.

A jogértelmezési kérdések kapcsán megemlítendő ebben a körben is az általános értelmezési keret, amely egyrészt az, hogy „az adóalap csökkentését (a költség érvényesitését) a jogalkotó döntése ('kegye') alapozza meg, és ezért csak egy egyértelmü rendelkezésre alapítható levonás”, ${ }^{63}$ másrészt pedig az, hogy „általában a szavak közismert és elfogadott jelentése szolgáltatja a jog értelmezésének alapját". ${ }^{4}$

Mivel a legváltozatosabb kiadások merülhetnek fel egy vállalkozás müködése, illetve személy tevékenysége során, ezért sokszor nehézséget okoz annak meghatározása, hogy az adott kiadás ténylegesen szükséges volt-e a vállalkozás müködéséhez kapcsolódóan, vagy sem. Az előbbi esetben jogszerü a figyelembevétele, az utóbbi esetben pedig nem. Az adózók érdeke nyilván, hogy a lehető legtöbb kiadást levonhassák költségként, ezért az adóhatóságoknak az ellenőrzések során azt is vizsgálniuk kell, hogy megfelelően értelmezték-e az adózók az adójogszabály által használt kifejezéseket.

A fogalmak értelmezése kapcsán meglehetősen jelentős döntés született a Welch v. Helvering ügyben (1933), ${ }^{65}$ amelynek tényállása szerint Thomas Welch és az apja egy gabonával foglalkozó ügynöki üzlet tulajdonosai voltak. A cég 1922-ben - nem a tulajdonosok szándékából kifolyólag - csődbe ment, azonban Welch később újraindította a vállalkozást, és úgy döntött, hogy visszafizeti a korábbi tartozásokat. A visszafizetéseket ezt követően költségként kívánta érvényesíteni, azonban az adóhatóság úgy foglalt állást, hogy ezek a tételek nem vonhatók le az adó alapjából. Az eljáró bíróság osztotta az adóhatóság álláspontját. Benjamin N. Cardozo bíró akként foglalta össze a kérdés lényegét, hogy figyelembe vehető-e annak a költsége, hogy egy megbízott ügynök igyekszik megerősíteni a saját hírnevét és hitelét. Az el is fogadható, hogy ezek a hitelezők javára teljesített kifizetések szükségesek voltak

62 Title 26 - Subtitle A - Chapter 1 - Subchapter B - Part VI.

${ }^{63}$ New Colonial Ice Co., Inc. v. Helvering, 292 U.S. 435 (1934).

${ }^{64}$ Maillard v. Lawrence, 57 U.S. 251 (1853).

${ }^{65}$ Welch v. Helvering, 290 U.S. 111 (1933). 
az adózó üzletének fejlesztéséhez, legalábbis abban az értelemben, hogy helyénvalóak és segítő jellegüek voltak. Azonban a kiadásnak nemcsak szükségesnek, hanem szokásosnak (ordinary) is kell lennie a jog megfogalmazása szerint. Hogy mi a szokásos, annak van egy állandó alapja, viszont a tényleges meghatározhatóság függ az időtől, a helytől és a körülményektől. A szokásos ebben az értelemben nem azt jelenti, hogy a kifizetésnek megszokottnak (rendszeresnek, gyakorinak) kell lennie. Így például egy, a vállalkozás biztonságát alapjaiban is megrendítő per talán egyszer fordul elő az életben, a jogi tanácsadói díjak olyan magasak, hogy valószínűtlen, hogy még egyszer megismétlődjön egy ilyen kereset a vállalkozással szemben. Azonban az ilyen kiadás szokásos, hiszen a kifizetett összeg akár magas, akár csekély, általános és elfogadott eszköze a védekezésnek. A helyzet egyedülálló az egyén életében, de nem egy csoport, közösség életében, amelynek a része. A választóvonal a konkrét ügy és a példa között világos - mutatott rá a bíró -, az emberek időnként kifizetnek olyan adósságot, amelyre törvény nem kötelezi őket, annak érdekében, hogy a megítélésükön javítsanak: ebben semmi szokásos nincs, sőt inkább „rendkívüli mértékünek” (a high degree extraordinary) tekinthető. „Ebben az esetben valójában - ahogy gyakran más jogágakban - az elhatárolás alapja valaminek a mértéke, és nem pedig a jellege." Sok olyan kiadás létezik, amelyek a sikerhez vezető utat jelentik; ezek között vannak olyanok, amelyek valóban célszerüek, helyesek, de nem szokásosak, nem sorolhatóak a vállalkozás müködéséhez kapcsolódó, szokásos költségek körébe (ezek inkább személyi, mintsem üzleti kiadások). Számos adójogi ítélet foglalkozik ezekkel a kérdésekkel, azonban ezek harmonizálása lehetetlen feladat lenne - fogalmazott az ítélet.

A felmerülő kiadások sokfélesége megnehezíti tehát az egységes jogalkalmazást, azonban vannak olyan fő irányok, amelyek figyelembe vehetőek. Vizsgálható így például a jogi költségek kérdése is, hiszen azok jellege, oka is különböző lehet. Az előző bekezdésben említett Welch v. Helvering ítélet hivatkozta a Cf. Kornhauser v. United States ügyet, ${ }^{66}$ amelynek tényállása szerint az adózó a korábbi partnerével elszámolási vitába került teljesített szolgáltatások ellenértéke kapcsán, mert úgy vélte, hogy a jogi kapcsolat még fennáll, a partner szerint azonban az már megszűnt. Az adózó sikerrel védte meg az álláspontját az ügyben, és az ügyvédi díj az adózó szerint levonható volt az adóból, mint szokásos és szükséges kiadás. A bíróság osztotta ezt a megközelítést: abból indult ki, hogy vannak követelések, amelyek érvényesítése jogi költségekkel jár. A bíróság példaként említette, hogy elfogadott költségként az, ha a vállalkozás ügyvédet bíz meg azért, hogy behajtsa jogos követeléseit egy nem fizetö ügyfélen. A tárgyalt esetben pedig nem másról volt szó, mint arról, hogy a már megszerzett jövedelmet kellett megtartani (megvédeni). „Egyik kiadás ugyanúgy az üzlethez kapcsolódik, mint a másik" - zárult az ítélet.

Említhető olyan eset is, amikor a bíróság megtagadta a felmerült jogi költségek levonhatóságát. A Lloyd v. Commissioner of Internal Revenue ügyben (1932) ${ }^{67}$ az adózó elnöke és nagyobb részt tulajdonosa is volt egy papíripari vállalkozásnak. $A z$ adózó 1924-ben részt vett az iparági szakmai szervezet éves összejövetelén, ahol

\footnotetext{
${ }^{66}$ Cf. Kornhauser v. United States, 276 U.S. 145 (1928).

${ }^{67}$ Lloyd v. Commissioner of Internal Revenue, 55 F.2d 842 (7th Cir. 1932).
} 
megtudta, hogy egy bizonyos W. T. P. Wardrop hamis állításokat terjeszt a megbízhatóságáról és a becsületéröl, amely állítások már a versenytársak és a vásárlók érdeklődését is felkeltették. Abból a célból, hogy megóvja a vállalkozását, az adózó rágalmazásért pert indított Wardrop ellen. Az adózási jogkérdés az volt, hogy a perhez kapcsolódó ügyvédi díjak levonatóak voltak-e a társaság adójából, vagy sem. A bíróság úgy foglalt állást, hogy nem a vállalkozás, hanem az adózó jó hírnevét érintette az ügy, az egyén sérelméért az egyén követelheti a kárai megtérítését, így szokásos és szükségszerű kiadásoknak az ilyen perek költségei nem minősíthetőek a vállalkozás részéről (hiszen a rágalmazás csak közvetetten érintette az adózó vállalkozását), így azok a személyes kiadások körébe sorolhatóak.

Az adott költségelem érvényesíthetőségéhez arra is szükség van, hogy az ténylegesen az adott vállalkozáshoz kapcsolódjon. A Deputy v. du Pont ügyben ${ }^{68}$ egy részvénykölcsönzés valósult meg, és ehhez kapcsolódóan állapítottak meg kifizetési kötelezettségeket. Az ügy tényállása szerint az adózó az E. I. du Pont de Nemours and Company (röviden: du Pont Company) nevü vállalkozásban (16\%-os mértékig) haszonélvező volt. A du Pont Company 1919-ben úgy döntött, hogy egy új, kilenc tagból álló igazgatóságot állít fel, amelynek tagjainak ösztönzésképpen 1000 USD értékü részvényt akartak juttatni, amely juttatás teljesítésére az adózó vállalkozott. Mivel azonban ezt a részvénymennyiséget nem volt képes biztosítani, ezért azt egy másik vállalkozástól, a Christiana Securities Companytől kölcsönözték 10 évre úgy, hogy kötelezettséget vállaltak a visszaszolgáltatásra és arra, hogy ezen időtartamra kifizetik a kölcsönzött részvényhez kapcsolódó összes osztalékot. Miután eltelt a 10 év, nem tudta az adózó biztosítani a visszatérítendő részvénymennyiséget, így egy másik vállalkozással, a Delaware Realty and Investment Co.-vel állapodott meg a szükséges részvénymennyiség átadására, hogy azokkal elégítse ki a Christiana Securities Company követelését. A megállapodásban azt vállalta az adózó, hogy amíg a részvényeket vissza nem adja, fizeti a kapcsolódó osztalékot és megtéríti az adókat. Ezek azok a kiadások, amelyek jogi megítélését kellett elvégezni a Deputy v. du Pont esetben.

A bíróság egyrészt megállapította, hogy az eredeti ügylet nem az adózóhoz, hanem a du Pont Company tevékenységéhez kapcsolódott, hiszen ők akarták a vezetőség teljesítményét ösztönözni a részvénycsomaggal. Másrészt megfogalmazták, hogy az ilyen kiadások nem tekinthetőek szokásosnak, hiszen e fogalom azt jelenti, hogy megszokott, normális, általános. Hivatkozott a Cf. Kornhauser v. United States ügyre a bíróság, amely szerint egy kiadás akkor is lehet szokásos, ha arra az életben egyszer kerül sor. Ugyanakkor az adózó alaptevékenysége nem részvénykereskedelem, a kérdéses ügylet nem kapcsolódott a tevékenységi köréhez. Utalt a bíróság a Welch v. Helvering esetre, amely szerint a szokásos elemnek vagy egy állandó tartalma, de azt befolyásolja az idő, a hely és az egyéb körülmények. A bíróság megállapította, hogy az említettek kívül esnek a szokásos kiadásokon, rendkívülinek tekintendők.

Ugyancsak nem veheti figyelembe levonható költségként a vállalkozás az olyan tartozások megfizetését, amelyek az adózói vállalkozásban részes egyén korábbi vál- 
lalkozásához köthetöek. A White v. Commissioner of Internal Revenue ügy (1932) ${ }^{69}$ tényállása szerint Willard W. White és Alva F. Page egy közös vállalkozást alapított egy gazdaság müködtetésére 1919-ben. Kölcsönt vettek fel a banktól, amely nemfizetés miatt jogi lépésekre kényszerült. A közös vállalkozás végül megszünt. White ezt követően egy új vállalkozást alapított Arthur P. Pollarddal (White \& Pollard). A megegyezésük kifejezetten szabályozta, hogy milyen korábbi kötelezettségeket ismer el (és melyeket nem) White. A bíróság szerint kimutatható volt, hogy a korábbi, az egyénhez köthető tartozásokat az új vállalkozás létrejöttét megelőzően halmozták fel, így azok nem a White \& Pollard céghez köthetőek, azokat ő nem vonhatja le az adójából. Nem fogadta el a bíróság azt az érvet, amely szerint a White \& Pollard jó hírneve szempontjából is rendkívül fontos az, hogy elkerüljék a korábbi kiegyenlítetlen tartozásból eredő pert, tekintettel arra is, hogy magát a vállalkozást nem terhelte kötelezettség.

Vizsgálható az adózó által önkéntesen fizetett jutalmak kérdése is, amelyek levonhatóságát a bíróság elfogadta egy esetben. A Lucas v. Ox Fibre Brush Co. ügy $(1930)^{70}$ tényállása szerint az adózó gazdasági társaság két tisztviselőjének külön jutalmat fizetett azért, hogy a társaság felvirágzását lehetővé tevő, elhivatott munkájukat (múltbeli szolgálataikat) honorálja. A bíróság is megállapította, hogy a két jutalmazott tevékenysége vezetett ahhoz, hogy a korábbi veszteséges vállalkozás nyereségessé válhatott. Ennek megfelelően elismerte, hogy nem merült fel sem viszszaélés, sem pedig adóelkerülési szándék, észszerü összegü, a hűséget és a hozzáértést elismerő ilyen kifizetés indokolható levonásnak minősítendő.

Más megítélés alá estek - nem voltak levonhatóak - azok a nem kötelező kifizetések a Blackwell Oil \& Gas Co. v. Commissioner ügyben, ${ }^{71}$ amelyeket a vállalkozás a részvényeseknek fizetett a közöttük fennálló vita rendezése érdekében. Ezen túlmenően - ugyancsak az említett ügyben - nem fogadták el levonható költségként azon összegeket, amelyek kifizetését azon perhez kapcsolódóan vállalta a társaság, amelyben az említett részvényesek alperesként szerepeltek. A tényállás szerint a részvényesek egy csoportja 1923-ban opciós megállapodást kötött egy személlyel, valamint jutalék kifizetését vállalták két személynek arra az esetre, ha az ügylet ténylegesen megvalósul. A jutalékra igényt tartó két személy egy hónappal később pert indított a vezetőség és a legfőbb részvényesek ellen, mivel az ügylet nem jött létre; álláspontjuk szerint az alperesek szövetkeztek (conspiracy) az ügylet meghiúsítására. A vezetőség úgy határozott, hogy a per nyomán felmerülö költségek megtérítését vállalják, illetve az egyezségekből eredő tartozásokat kifizetik. A bíróság szerint a társaság nem volt részese az összeesküvésnek, a vezetőknek nem volt a társaság részéröl felhatalmazásuk ilyen jogellenes tevékenységre. Miután a társaság nem volt felelős a per alapját szolgáló helyzet kialakulásáért, az erre tekintettel teljesített kifizetések sem minősíthetőek a társaság részéröl szokásosnak és szükségesnek.

Végül megemlíthető a jótékonyság egy speciális esete. Az American Rolling Mill Co. v. Commissioner of Internal Revenue ügy $(1930)^{72}$ tényállása szerint a vállalko-

\footnotetext{
69 White v. Commissioner of Internal Revenue, 61 F.2d 726 (9th Cir. 1932).

${ }^{70}$ Lucas v. Ox Fibre Brush Co., 281 U.S. 115 (1930).

${ }^{71}$ Blackwell Oil \& Gas Co. v. Commissioner of Internal Rev., 60 F.2d 257 (10th Cir. 1932).

72 American Rolling Mill Co. v. Commissioner of Internal Revenue, 41 F.2d 314 (6th Cir. 1930).
} 
zás egy ohiói városban működtetett fém- és acélipari üzemet, a város keresőképes lakosságának felét foglalkoztatva. Fontossá vált a munkások helyzetének javítása, hiszen a környező településeken sztrájkok voltak. Mivel csak egy kis kórház és egy kis közösségi ház állt rendelkezésre a városban, ezért az adózó 1919-ben egy javaslatot tett a kereskedelmi kamarának egy tervre, amely keretében a város cégei felajánlásokat tesznek civil közösségi fejlesztési célokra. A bíróság megítélése szerint az így tett felajánlások költségként az adózó számára levonhatóak voltak, hiszen nem egyszerü jótékonyságról volt szó, hanem arról, hogy munkások körülményeinek, képességeinek javulása folytán növekedjen a cég termelékenysége is. Fontos tehát a kifizetés célja: bár az adózó célja a profit termelése, nem a munkások ellátása, a vállalkozás mégis hosszú évek óta sikeresen működött a dolgozói körülmények javításának elvét követve (és ez a siker tette lehetővé egyáltalán a felajánlás megtételét).

Összegezve a fentieket: különböző bírói fórumok számtalan döntésben foglalkoztak és foglalkoznak azzal a kérdéssel, hogy milyen költségelemeket lehet a szokásos és szükséges körbe bevonni, és ezáltal levonni az adóból. A fenti ítéleteket áttekintve a következő főbb jellemzőket, elveket lehet megfogalmazni:

- Fontos követelmény, hogy el kell egymástól határolni a vállalkozás és a vállalkozáshoz kapcsolódó egyén (például részvényes, igazgató, tulajdonos) egyéni, személyes érdekeit. Még ha az adott kiadást a vállalkozás is teljesíti, akkor sem feltétlenül az ő érdekeit szolgálja közvetlenül, elképzelhető, hogy csak közvetett a kapcsolat a kiadás és a vállalkozás helyzete (tevékenysége, céljai) között.

- Ha több vállalkozás is érintett a kérdéses adózói kiadást megalapozó jogügyletben, akkor értelemszerűen vizsgálni kell azt, hogy az adott kiadás ténylegesen melyik vállalkozáshoz kapcsolható.

- Az adott költségnek a vállalkozáshoz (foglalkozáshoz) kapcsolódóan szokásosnak és szükségesnek kell lennie egyszerre. Ha nem áll fenn egyidejüleg a két elem, akkor a kiadás érvényesíthetősége (levonhatósága) megtagadható. Vizsgálni kell tehát az egyes esetekben, hogy egy adott vállalkozás életében mi tekinthető szokásosnak, szükségesnek. Mivel a gazdasági életben rendkívül sokféle döntés, illetve bonyolult jogügylet merül fel, ezért rendkívül fontos az említett fogalmak megfelelő elemzése. Ehhez elengedhetetlen a korábbi bírósági ítéletekben elvként használható (használandó) tartalmak megismerése.

\section{Az aktuális szabályozás - az economic substance doctrine}

A különböző értelmezési módszerek alkalmazására vonatkozó példák, mérföldkövek és alapvető koncepciók bemutatását követően felmerül egy alapvető kérdés: miképpen kell a jogszabályokat értelmezni (alkalmazni) akkor, ha adóelkerülési szándék tulajdonítható az adózónak. Ennek megfelelően szükséges a hatályos jogszabályi környezet és bíró alkotta jog összefoglalása is. Elsőként az ecocomic substance doktrína elméleti alapjai vázolandóak fel, amelyek kijelölik, hogy az adózó által megvalósított ügyleteket mikor lehet adózási szempontból indokoltnak (elfogadhatónak) tekinteni. 
Az economic substance doctrine, azaz a gazdasági tartalom vizsgálatának doktrínája megjelenik mind a szövetségi, mind az állami adójogi jogértelmezésben, és fontos eszközként használható az adóelkerülés elleni küzdelemben, a rá vonatkozó keretek megtartásával. A kiindulópont az, hogy az adótörvény nem használható saját maga ellen, illetve az adó megkerülésére. A doktrína egy értelmezési módszer, amely azért jött létre, hogy egyensúlyt teremtsen a közpénzek védelme és az adózók biztonságra, kiszámíthatóságra és bizalomra vonatkozó igénye között, továbbá célja az adójogszabályok szerkezeti integritásának fenntartása. ${ }^{73}$

E megközelítés kidolgozásában kulcsszerepe volt Learned Hand bírónak, aki a Gilbert v. Commissioner ügyben $(1957)^{74}$ fogalmazott meg egy fontos különvéleményt, de ezt megelőzően a doktrína elvi alapjait már a Helvering v. Gregory ítéletben ${ }^{75}$ kialakított állásponttal lefektette az 1930-as években (korábban és ezt követöen is írt számos olyan véleményt, amely az adótörvények nyelvtani értelmezésével és az adóelkerülésre vonatkozó doktrínákkal foglalkozott, de a Gilbert-ügyben megfogalmazott különvéleménye volt az utolsó és egyben legjelentősebb, az adóelkerülésről kifejtett álláspontja). ${ }^{76}$ Megjegyzendő, hogy a Gregory-ítéletben is megjelent az az alapvető kiindulópont, amely szerint „Mindenkinek lehetősége van úgy intézni az ügyeit, hogy a lehető legkevesebb adót kelljen fizetnie; nem kötelező olyan megoldást választani, amely a Kincstár számára a legkedvezőbb; és hazafias alapon sem lehet több adót követelni." "77 A jogvitában a központi kérdés az volt, hogy adómentes társasági reorganizáció valósult-e meg, vagy sem a következő tényállás mellett: Evelyn Gregory tulajdonosa volt az összes részvénynek a United Mortgage Companyben, amely pedig 1000 részvényt birtokolt a Monitor Securities Corporation nevủ társaságban. Gregory 1928. szeptember 18-án létrehozta az Averill Corpot, és három nappal később a Monitor 1000 részvényét átruházta az Averillre. Ezt követően, szeptember 24-én megszüntette az Averillt, a Monitor-részvényeket magának osztotta, és ugyanezen a napon eladta őket több mint 130000 USD-ért. Az 1928. évre vonatkozó adóbevallásában több mint 57000 USD költséget kívánt érvényesíteni. Az adóhatóság képviselője (Guy T. Helvering) azonban úgy ítélte meg, hogy semmiféle reorganizáció nem valósult meg, csak jogi lépések történtek annak érdekében, hogy annak a látszatát keltsék. A Legfelsőbb Bíróság az adóhatóság álláspontját osztotta, megállapítva azt, hogy bár létrejött érvényesen egy új társaság, de azért a „tények önmagukért beszéltek”.

A Gilbert-ügy alapvető kérdése pedig az volt, hogy egy társaság részére fizetett összeg kölcsönnek vagy pedig a tőkéhez való hozzájárulásnak tekintendő-e. Az eset tényállása szerint a Gilbor nevű társaságban Benjamin Gilbert és egy másik magánszemély voltak tulajdonosok egyenlő arányban. Benjamin felesége, Madeline nem volt tulajdonos a cégben. A társaság egy sor sikertelen vállalkozásba fogott,

\footnotetext{
${ }^{73}$ KolariK, William Joel II-WLodychaK, Steven Nicholas John: The Economic Substance Doctrine in Federal and State Taxation. Tax Lawyer, 2014/4, 721.

${ }^{74}$ Gilbert v. Commissioner, 248 F.2d 399, 410-12 (2d Cir. 1957).

${ }^{75}$ Helvering v. Gregory, 69 F.2d 809 (2d Cir. 1934), Gregory v. Helvering, 293 U.S. 465 (1935).

${ }^{76}$ KolARIK-WLODYCHAK, i. m. 730-731.

77 „Any one may so arrange his affairs that his taxes shall be as low as possible; he is not bound to choose that pattern which will best pay the Treasury; there is not even a patriotic duty to increase one's taxes."
} 
ami azt eredményezte, hogy további befektetések váltak szükségessé Benjamin és Madeline részéről, amelyet kölcsönként kezeltek. A Gilbor Inc. 1948-ban felszámolás alá került, és a házaspár a közös jövedelemadó-bevallásukban a kölcsön összegét, mint behajthatatlan követelést vonták le az adójukból. Az adóhatóság azonban ezt megtagadta, arra hivatkozással, hogy ez tőke-hozzájárulás volt, és nem pedig egy tényleges adós-hitelező viszonyt létrehozó kölcsön, Madeline esetében pedig az is érv volt, hogy az általa elszenvedett veszteség nem a kereskedelmi (vállalkozási) tevékenysége körében merült fel. ${ }^{78}$

A Gilbert-ítéletben kidolgozott tesztet a Legfelsőbb Bíróság a Knetsch v. United States ügyben (1960) ${ }^{79}$ vette át; bár ezt szokták economic substance doctrine-nak nevezni, az alapul fekvő magyarázat és az alkalmazás határai lényegében változatlanok. Marvin A. Chirelstein professzor akként foglalta össze a doktrína lényegét, hogy a kétes tartalmú ügyleteket az adóhatóság javára kell értelmezni, kivéve, ha az adózó képes annak alátámasztására, hogy az általa választott jogi megoldás gazdasági hatást is kiváltott vagy várhatóan ki fog váltani az adómegtakarításon túlmenően. Kétesnek az olyan ügylet tekintendő, amely valószínúsíthetően többféle módon értelmezhető. Az is lényeges, hogy e doktrína alkalmazása különböző korlátok közé esik, így például csak nyilvánvaló ügylettel kapcsolatban alkalmazható (az adózó részéről valamitől történő tartózkodásra, így például arra, hogy késlekedett valamely vagyontárgy értékesítésével, nem), az adóhatóság - a szokatlan körülmények kivételével - nem hagyhatja figyelmen kívül az előny jellemzőit, továbbá az adóhatóság nem jogosult olyan ügyletek felülbírálatára, amelyek független felek között jöttek létre, és amelyek kialkudott árat vagy más megállapodást tartalmaznak (a Gilbert-teszt az ún. self-dealing esetekre alkalmazható). ${ }^{80}$

A common law-ban megjelent elvet immár a tételes jog szabályozza az IRC 7701. §-ában „Clarification of economic substance doctrine” cím alatt; a kodifikációra 2010-ben került sor a Kongresszus részéről, az értelmező rendelkezés megfogalmazásával. Az egyetlen olyan másik rendelkezés az IRC-ben, amely hivatkozik erre a meghatározásra, a 6662. § (b)(6), amely büntetés kiszabását rendeli az olyan ügyletekre, amelyek nem teljesítik a definícióban foglalt követelményeket. A 7701 . $\S$ common law elvként hivatkozza az economic substance doctrine-t, ami azt jelenti, hogy a jogalkotó nem változtatta meg a joggyakorlatban kialakult megközelítéseket. ${ }^{81}$ A szabályozás értelmében csak azon ügyleteknek (ügyletek sorozatának) van gazdasági tartalma, amelyek esetében fennáll a két következő feltétel: (a) az ügylet jelentősen - a szövetségi jövedelemadó hatásait leszámítva - megváltoztatja az adózó gazdasági helyzetét, és (b) az adózónak jelentős célja van - a szövetségi jövedelemadó hatásait leszámítva - az ügylet megvalósításával.

A tételes jog bemutatását követően megemlítendő egy, a modern economic substance doctrine szempontjából kiemelkedően fontos ügy, mégpedig az ACM

\footnotetext{
78 KOLARIK-WLODYCHAK: i. m. 737.

${ }^{79}$ Knetsch v. United States, 364 U.S. 361 (1960).

${ }^{80}$ KOLARIK-WLODYCHAK: i. m. 742-743.

${ }^{81}$ KOLARIK-WLODYCHAK: i. m. 771.
} 
Partnership v. Commissioner eset (1998). ${ }^{82}$ Az ítéletben William Greenberg bíró megfogalmazta, hogy a doktrínának van egy objektív és egy szubjektív oldala. Az objektív oldal azt jelenti, hogy arra a kérdésre kell választ adni, hogy van-e az ügyletnek bármilyen gyakorlati hatása az adó csökkentésén kívül; a szubjektív oldal pedig azt, hogy az adózói indokok vizsgálandóak, vagyis az, hogy az adózó egy hasznos, nem adózási szempontú cél megvalósítására törekedett-e, és az, hogy észszerủen elvárható volt-e az adózás előtti profit elérése. Az objektív economic substance doctrine-t ugyanazzal a célkutató értelmezési módszerrel vizsgálta, amelyet Hand bíró is alkalmazott a Gregory-ügyben (ugyanúgy talált egy íratlan definíciót a veszteség fogalmára az IRC rendelkezései között, mint ahogyan Hand bíró talált egy hasonló íratlan meghatározást 60 évvel korábban a reorganizációra). Ez a döntés tehát azért jelentős, mert egyrészt kifejezésre juttatta a modern doktrínát, másrészt pedig azért, mert újraélesztette a célkutató törvényi értelmezés azon módszerét, amely a Gregory-ügyben is megjelent. ${ }^{83}$

Végül megjegyzendő, hogy nem az economic substance doctrine az egyetlen olyan elv a common law-ban, amelyet a bíróságok alkalmaznak az adóelkerülés megakadályozása érdekében. Megemlíthető még a színlelt ügyletek megítélése (Sham Transaction Doctrine), amikor az ügylet nem vagy nem úgy történt, ahogyan azt dokumentálták (csak papíron létezik); az adózó motivációjának vizsgálata (Business Purpose Doctrine, amely szerint vizsgálható, hogy az ügylettel kizárólag az adóelőny megszerzése volt-e a cél); a tartalom elsődlegessége a formával szemben (Substance Over Form Doctrine), amely elv szerint azon különböző ügyletek, amelyek ugyanazon eredményt idézik elő, nem kezelhetőek adózási szempontból eltérő módon kizárólag azon az alapon, hogy az adózó az eredményt különböző jogi lépések útján érte el. ${ }^{84}$

\section{5. Összegző gondolatok}

A jogértelmezés alapvető problémája annak megállapítása, hogy az adott történeti tényállást a jogalkotó hogyan kívánta megítélni, vagyis fel kell tárni a norma tartalmát, és annak megfelelően kell levonni a jogi következtetéseket. Az alapvető módszer a nyelvtani értelmezés: a szavak általános jelentése, kötőszavak használata az elsődleges kiindulópont, de vannak olyan helyzetek, amikor e módszer alkalmazása nem vezet elfogadható eredményre, ezért már összetettebb értelmezési, vizsgálati tevékenységet kell végezni.

Az Egyesült Államok bemutatott ítélkezési gyakorlatában is visszatérő kérdés, hogy hol húzódik az a határ, ameddig a szó szerinti értelmezés módszere alkalmazandó, és amelynek átlépésével már az eredmény abszurd lenne, és ezért el kell rugaszkodni a norma szó szerinti értelmezésétől, és más elvek alkalmazásával kell a kérdéses esetet megítélni. E kérdés megválaszolása már a jogalkalmazói belátá-

\footnotetext{
82 ACM Partnership v. Commissioner, 157 F.3d 231, 247 (3d Cir. 1998).

83 KOLARIK-WLODYCHAK: i. m. 755-757.

${ }^{84}$ KOLARIK-WLODYCHAK: i. m. 760-761.
} 
son múlik egy-egy adott ügyben, bár a jogalkotó is indokoltnak látta kodifikáció útján kijelölni a vonatkozó vizsgálatokra vonatkozó szabályokat. Ha nem áll fenn különleges helyzet, akkor a szavak nyelvtani értelmezéséből kell kiindulni, és azok alapján kell elbírálni a jogvitát.

A tanulmány alapvető célkitűzése az említett példák bemutatásával az volt, hogy a gyakorlatban felmerült különféle tényállásokat (adózói döntéseket, ügyleteket) vizsgáló ítéletekkel rámutasson arra, hogy a jogalkalmazónak milyen kihívásokkal kell szembesülnie egy-egy jogvita elbírálásakor, milyen keretek, koncepciók használhatóak fel e feladat teljesítéséhez. Alapvető célkitűzés, hogy az adózók védelme a jogalkotói, jogalkalmazói hiányosságokkal, túlkapásokkal szemben biztosított legyen, ugyanakkor érvényre kell juttatni a közérdeket is, vizsgálni kell az adóelkerülési szándékot (a joggal való visszaélést), és ennek megfelelően kell a jogértelmezést elvégezni, a konkrét esetet elbírálni.

Bár a tanulmány alapvetően a 19. században és a 20. század első két harmadában keletkezett bírósági döntéseket tárgyalta, ez nem jelenti azt, hogy az ítéletek kizárólag jogtörténeti jelentőséggel bírnának, hiszen a bemutatott döntésekben munkálták ki azokat az elveket, megközelítéseket, amelyek napjainkban is kiindulópontok vagy éppen meghatározó jelentőségüek lehetnek. Különösen fontosak azok a jogalkotói és jogalkalmazói törekvések, amelyek az adóelkerülés megakadályozására irányulnak: a jogalkotónak lehetősége van a bírói jogban kimunkált elveket, teszteket a tételes jogba is beépíteni, de kodifikáció nélkül is alkalmazandóak a különböző, a common law-ban megjelent doktrínák az adójogi tényállások (az adózói döntések, ügyletek) megítélésére.

\section{Abstract}

The Interpretation of Tax LaW in the Precedents of the United States of America The proper interpretation of the legal provisions in the field of tax law has high importance because it determines the opportunities of the taxpayers. Taxpayers normally wish topay as little tax as possible, in contrast, the tax authorities try to collect as much tax as, according to them, is still lawful. If a taxpayer makes an error in his legal interpretation, he has to face the legal consequences, that is why it is necessary to know the case law. In the English law and in the law of the United States, two fundamental approaches of the interpretation of tax law have emerged: according to the strict approach, the judicature has to scrutinize only the meaning of the words of the act and that is what determines the question of the tax burden. On the other hand, the other approach means that the purpose of the questionable transaction or the intention of the legislator shall be taken into consideration as well, but only in that case in which the application of the words would lead to an unreasonable result. This paper analyzes the relevant precedents of the United States, mentioning many examples and scrutinizes the theoretical bases and the application of the two approaches mentioned. 